ORIGINAL ARTICLE

\title{
Assessment of fire hazard weather indices in the eastern Amazon: a case study for different land uses
}

\author{
Rosane B.L. CAVALCANTE ${ }^{1 *} \odot$, Bruno M. SOUZA ${ }^{1,2}$, Silvio J. RAMOS ${ }^{1}$, Markus GASTAUER ${ }^{1}$, \\ Wilson R. NASCIMENTO Junior ${ }^{1}$, Cecílio F. CALDEIRA ${ }^{1}$, Pedro W.M. SOUZA-FILHO ${ }^{1}$ \\ 1 Instituto Tecnológico Vale, R. Boaventura da Silva, 955, 66055-090, Belém, Pará, Brazil \\ 2 Biopalma da Amazônia S.A., Av. Alcindo Cacela 1264, 66040-020, Belém, Pará, Brazil \\ *Corresponding author: rosanecavalcante@gmail.com; (1) https://orcid.org/0000-0002-5941-6460
}

\begin{abstract}
The fire frequency in the Amazon increased rapidly after the 1990s due to deforestation and forest degradation, and it is expected to increase in response to climate change. We analyzed the fire occurrence and assessed seven fire hazard indices in the municipality of Canaã dos Carajás, in the eastern Amazon, for different land use and land cover (LULC) types. We used data from three weather stations located at different heights to compare the performance of the indices using skill scores and success percentages for each LULC. Overall most hotspots occurred in deforested areas and native forests, which were the main LULC types, while few were observed in rupestrian fields, urban areas, and mining areas. However, forests presented the lowest number of hotspots per unit area, especially inside protected areas, and all hotspots in forest areas were observed after a severe drought in 2015. The performance of the fire indices varied as a function of the LULC class and the weather station considered, which indicates the importance of choosing the most appropriate location of the station according to the purpose of the monitoring. The Keetch-Byram Drought Index showed the best performance for predicting fire occurrence for all LULC classes, and forests and deforested areas individually. Despite its simplicity, the Angstrom index stood out due to its good performance in the prediction of days with more than six hotspots.
\end{abstract}

KEYWORDS: forest protection, conservation units, fire index, KBDI, Angstrom index

\section{Avaliação dos índices climáticos de perigo de incêndio na Amazônia oriental: um estudo de caso para diferentes usos do solo}

\section{RESUMO}

A frequência dos incêndios na Amazônia aumentou rapidamente após a década de 1990 devido ao desmatamento e degradação florestal, e espera-se que continue aumentando em resposta às mudanças climáticas. Analisamos a ocorrência de incêndios e avaliamos sete índices de perigo de incêndio no município de Canaã dos Carajás, na Amazônia oriental, para diferentes tipos de uso e cobertura do solo. Usamos dados de três estaçôes meteorológicas situadas em diferentes altitudes para comparar o desempenho dos índices usando skill scores e porcentagens de sucesso para cada uso do solo. Em geral, a maior parte dos focos de calor ocorreu em áreas desmatadas e florestas nativas, que têm as maiores áreas de cobertura no município, enquanto poucos focos foram observados nas áreas de campo rupestre, urbanas e de mineração. No entanto, as florestas apresentaram o menor número de focos de calor por unidade de área, especialmente dentro de áreas protegidas, e todos os focos em floresta foram observados após uma seca severa em 2015. O desempenho dos índices de incêndio variou em função do uso do solo e da estação meteorológica utilizada, mostrando a importância da escolha da localização apropriada da estação, conforme o objetivo do monitoramento. O Índice de Seca Keetch-Byram apresentou o melhor desempenho para predizer a ocorrência de incêndios considerando todos os usos do solo, e para as áreas de floresta e desmatadas separadamente. Apesar de sua simplicidade, o índice de Angstrom se destacou por seu desempenho na predição de dias com mais de seis focos de calor detectados.

PALAVRAS-CHAVE: proteção florestal, unidades de conservação, índice de incêndio, KBDI, índice de Angstrom 


\section{INTRODUCTION}

In recent decades, the expansion of the agricultural frontier has led to significant changes in land use and land cover (LULC) in the southern and eastern Amazon (Souza-Filho et al. 2016; Souza-Filho et al. 2019). While few fires occurred in this region before 1987 , the fire frequency increased rapidly during the 1990s due to deforestation and forest degradation, representing an important emission of greenhouse gases (Marle et al. 2017; Pletsch et al. 2018). Fires are applied for land clearing and cattle pasture and agriculture maintenance in the Amazon (Nepstad et al. 2006). Furthermore, pastures and previously burned forest areas exhibit higher midday temperatures, lower relative humidity, and higher flammability than primary forest (Gerwing 2002; Uhl and Kauffman 1990), thereby changing the fire dynamics (Ray et al. 2005) and elevating the fire risk. Climate change in combination with ongoing deforestation will increase fire occurrence in $50 \%$ of protected areas in the Amazon through 2050 (Silvestrini et al. 2011); thus, effective plans are required to ensure biodiversity, ecosystem structure, and public health (Schroeder et al. 2009).

The use of fire indices is important for identifying the fire risk in a region, performing fire control planning, identifying the best times for controlled burning, generating fire behavior forecasts, and providing danger alerts to society and firefighting teams (Holsten et al. 2013; Torres et al. 2017). These indices represent practical tools to protect forests, biodiversity, and local communities from fire risk (Chitale and Behera 2019; Gaigher et al. 2019). Most fire indices use meteorological variables that are routinely monitored by weather stations (such as air temperature, humidity, precipitation, and wind speed) to account for atmospheric conditions, vegetation dryness, and flammability (Chuvieco et al. 2010). However, fire indices based only on meteorological data do not consider human influences and differences in fuel loads and micrometeorological conditions between LULC classes, which may influence fire ignition and propagation (Taylor et al. 2006). Additionally, the closest weather station may not be representative of the entire area of interest.

This study aimed to analyze the fire occurrence in a municipality (Canaã dos Carajás) in the eastern Brazilian Amazon and compare the performance of seven fire indices based on meteorological data to optimize fire hazard forecasting. We computed the fire indices using data from three weather stations situated at different altitudes and LULC classes and compared their performance in detecting days with fire events (hotspots detected by remote sensing) in each LULC class.

\section{MATERIAL AND METHODS}

\section{Study area}

The study area was the municipality of Canaã dos Carajás (06029'49"S, 49०52'42W), which is located in the mesoregion of southeastern Pará state, Brazil, in the Carajás Mineral Province (Figure 1). The eastern Amazon has the highest number of fires in the Amazon region (Miranda et al. 2006),

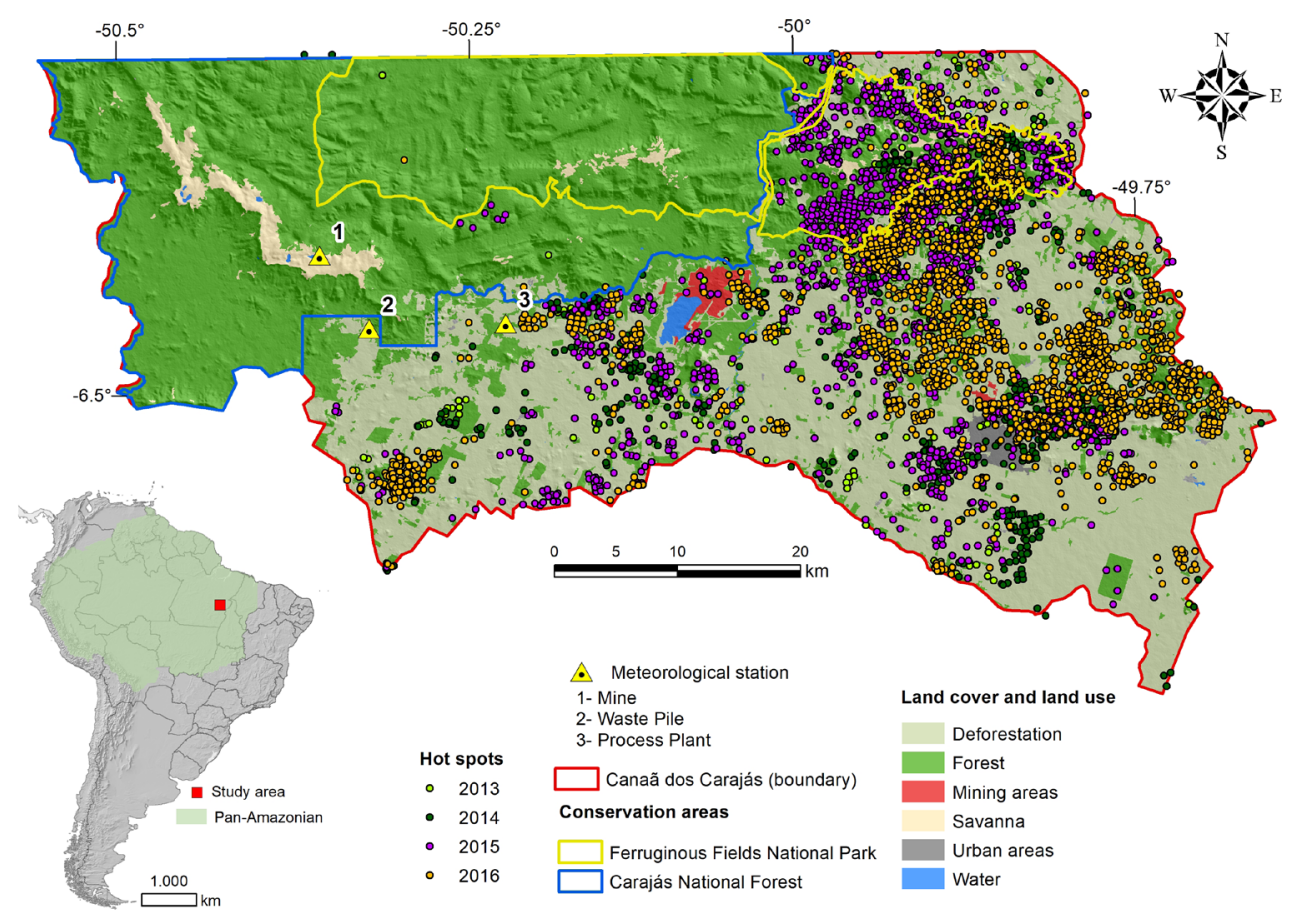

Figure 1. Location of the municipality of Canaã dos Carajás in the eastern Brazilian Amazon region, and distribution of land use and land cover (LULC) classes in Canaã dos Carajás in 2013, and of total detected hotspots from 2013 to 2016. The location of the three weather stations used for fire hazard index calculations is also shown. This figure is in color in the electronic version. 
and the vast majority are associated with agricultural activities. Canaã dos Carajás presents LULC types that typically coexist in the region (protected areas with forest, cattle ranching, urban areas, and mining). The municipality has a total area of $3,146 \mathrm{~km}^{2}$ and emerged from a rural settlement established in the early 1980s. Approximately one third of the municipality's area $\left(1,142 \mathrm{~km}^{2}\right)$ is within conservation units. There are two large mining operations in the municipality that began one in the early 2000s and the other in 2016 .

The climate in the region is classified as tropical monsoon (temperature of the coldest month about $18^{\circ} \mathrm{C}$, rainfall of the driest month less than $60 \mathrm{~mm}$, and annual rainfall above $2500 \mathrm{~mm}$ ) according to Köppen's climate classification, in the transition between tropical areas with and without a dry season (Alvares et al. 2013). The west portion of the municipality presents high altitude with flattened tops and a set of ridges and peaks that can reach more than $800 \mathrm{~m}$ of altitude, while areas of lower and flattened terrain dominate the east. The remaining native vegetation is concentrated within the conservation units situated in the west of the municipality. The rainforest predominates but there are "islands" of natural rupestrian fields (ferruginous lateritic formations known as cangas) on the higher areas (Souza-Filho et al. 2019).

\section{LULC classification}

We used the LULC classification from Souza-Filho et al. (2016). The following classes were considered: forests (including primary and secondary forests), pasture and agricultural areas (both included in a single category called deforestation from now on), urban areas, rupestrian fields, mining areas, and water bodies. According to this classification, in 2013 , the municipality had $1,632 \mathrm{~km}^{2}$ of forests, $1,369 \mathrm{~km}^{2}$ of deforested areas, $67 \mathrm{~km}^{2}$ of rupestrian field, $16 \mathrm{~km}^{2}$ of urban areas, $16 \mathrm{~km}^{2}$ of mining, and $6 \mathrm{~km}^{2}$ of water surface (Souza-Filho et al. 2016). These areas were assumed to be constant throughout the study period.

\section{Weather data}

Data from three meteorological stations from a mining project were used to determine the meteorological fire indices. Information on the location, altitude, and land use in the vicinity of the stations is shown in Table 1 . The following meteorological data were collected hourly from 2013 to 2016: cumulative precipitation, air relative humidity, air temperature, and wind speed.

Table 1. Location (datum WGS 1984), altitude and predominant land use and land cover (LULC) types surrounding three weather stations in Canaã dos Carajás (Pará, Brazil) used for computation of different fire hazard indices.

\begin{tabular}{lcccc}
\hline $\begin{array}{l}\text { Weather } \\
\text { station }\end{array}$ & $\begin{array}{c}\text { Altitude } \\
(\mathbf{m})\end{array}$ & Latitude & Longitude & $\begin{array}{c}\text { Main LULC in a 5-km } \\
\text { radius }\end{array}$ \\
\hline Mine & 740 & -6.39711 & -50.34871 & $74 \%$ forest, $25 \%$ rupestrian \\
field
\end{tabular}

\section{Fire hazard weather indices}

Seven fire indices based on meteorological data were calculated daily and tested for accuracy based on forest fire occurrence: Angstrom index, Rodríguez and Moretti index (IRM), Monte Alegre Formula (FMA), Altered Monte Alegre Formula (FMA+), Keetch-Byram Drought Index (KBDI), Forest Fire Danger Index (FFDI), and Forest Fire Weather Index (FWI). These indices were already tested to forecast the fire danger in Brazil (Casavecchia et al. 2019; Ziccardi et al. 2020; Nogueira et al. 2017), and they require data that are usually available from weather stations. Additionally, the last three indices include estimates of soil moisture, which could improve fire danger forecast.

The Angstrom index (Angstrom 1942), developed in Sweden, is a noncumulative index that determines the fire hazard according to equation 1. Angstrom indices less than 2.5 indicate elevated fire hazard risk.

$B=0.05 \cdot R H-0.1 \cdot(T-27)$

(equation 1)

where $R H=$ relative humidity (\%) at $1 \mathrm{p} \cdot \mathrm{m}$. and $\mathrm{T}=$ air temperature $\left({ }^{\circ} \mathrm{C}\right)$ at 1 p.m.

The IRM (Rodríguez and Moretti 1988) was developed for the Andean-Patagonian region and uses air temperature, relative humidity, wind speed, and consecutive days without precipitation (precipitation less than $2 \mathrm{~mm}$ ). The input variables are obtained from the daily observations made at 3 p.m. The computation is performed by summing the four values of the accumulators (Supplementary Material, Table S1) for consecutive days without precipitation. When precipitation occurs, the value considered in the accumulator for the number of days without rain is 0 . The IRM is expressed on a scale of 0 to 100 , and the hazard risk is classified as low (between 0 and 24), moderate (25-49), high (50-74) or extreme (75-100).

The FMA index (Soares 1972) is calculated according to equation 2. It emphasizes the probability of ignition, and was developed and validated for the region of Telêmaco Borba in Brazil (humid subtropical climate) and is adjusted as a function of the precipitation amount (Supplementary Material, Table S2). The fire hazard risk is classified as null ( $\leq 1.0$ ), small (1.1 to 3.0$)$, medium (3.1 to 8.0), high (8.1 to $20)$, or very high $(>20)$.

$$
F M A=\sum_{i=1}^{n} \frac{100}{R H}
$$

(equation 2)

where $R H=$ relative humidity $(\%)$ and $n=$ the number of days without rain greater than or equal to $13.0 \mathrm{~mm}$. 
The FMA+ is a modification of the FMA by Nunes et al. (2006). It includes wind speed (equation 3) to assess the potential fire propagation. The fire hazard rating for FMA+ is classified as null $(\leq 3.0)$, small (3.1 to 8.0$)$, medium (8.1 to 14 ), (high 14.1 to 24$)$, or very high (>24).

$$
F M A^{+}=\sum_{i=1}^{n}\left(\frac{100}{R H_{i}}\right) \cdot e^{0.04 \cdot v}
$$

where $R H=$ relative humidity (\%), $n=$ number of days without rain greater than or equal to $13.0 \mathrm{~mm}$, and $v=$ wind speed $(\mathrm{m} / \mathrm{s})$.

Both FMA and FMA+ have been successfully tested to forecast the fire danger in other regions of Brazil (e.g., Alvares et al. 2014; Borges et al. 2011; White et al. 2015) and other countries (Rodriguez et al. 2012; Mbanze et al. 2017).

The KBDI is a drought index originally developed to assess fire risk in the USA, particularly in Florida (Keetch and Byram 1968). The KBDI has become widely used in wildfire monitoring and prediction (Heim 2002). The index conceptually estimates the soil moisture deficit based on a simple daily soil water balance (equations 4, 5, and 6). The moisture deficiency is correlated with the fire potential: 0-200 represents a low fire potential, 200-400 moderate, 400-600 high, and 600-800 very high fire potential (Liu et al. 2013).

$$
\begin{aligned}
& \left.K B D I^{t}=K B D I^{t-1}+D F^{t}-R F^{t} \quad \text { (equation } 4\right) \\
& \left.D F^{t}=\frac{\left(203-K B D I^{t-1}\right)\left(0.968 e^{\left(0.0875 \cdot T_{m}+1.552\right)}-8.3\right) \cdot 10^{-3}}{1+10.88 e^{\left(-0.001736 \cdot R_{0}\right)}} \text { (equation } 5\right) \\
& R F^{t}=\left\{\begin{array}{c}
\left(R^{t}-5.1\right), R^{t} \geq 5.1 \frac{\mathrm{mm}}{d a y}, 1 \text { st rainy day } \\
R^{t}, R^{t-1} \geq 5.1 \frac{\mathrm{mm}}{d a y}, 2 n d \text { and the next rainy day } \\
0, R^{t}<5.1 \mathrm{~mm} / \text { day }
\end{array}\right.
\end{aligned}
$$

(equation 6)

where KBDI $=$ moisture deficiency $(\mathrm{mm}), \mathrm{DF}=$ drought factor $(\mathrm{mm}), \mathrm{Tm}=$ daily maximum air temperature $\left({ }^{\circ} \mathrm{C}\right), \mathrm{R}_{0}$ $=$ average annual rainfall $(\mathrm{mm}), \mathrm{RF}=$ rainfall factor $(\mathrm{mm})$, $\mathrm{R}=$ daily rainfall $(\mathrm{mm})$, and $\mathrm{t}$ indicate the calculation day.

The FFDI (McArthur 1967) is widely used in Australia as a basis for issuing fire weather warnings, and it is calculated using the equations by Noble et al. (1980) (equation 7). The DF is partly based on the soil moisture deficit that was calculated using KBDI (Finkele et al. 2006). For eastern Australia, the index is classified as low (0-5), moderate (5-12), high (12-24), very high (24-50), severe (50-75), extreme (75$100)$, and catastrophic (>100).

$F F D I=2 e^{(-0.45+0.987 \ln (D F)-0.0345 R H+0.0338 T+0.0234 v)}$

(equation 7)

where $\mathrm{T}=$ temperature $\left({ }^{\circ} \mathrm{C}\right), \mathrm{v}=$ wind $\operatorname{speed}\left(\mathrm{km} \cdot \mathrm{h}^{-1}\right), \mathrm{RH}=$ relative humidity (\%), and DF $=$ Drought Factor, a component that represents fuel availability.

The FWI (Van Wagner 1987) is based on the effects of weather parameters on forest floor fuel moisture conditions. It was primarily developed for the pine fuel type in Canada. It has been used in day-to-day operational fire management activities to measure general forest fire danger in Canada (Johnston et al. 2020) and was tested in other countries (e.g.: Varela et al. 2018; Masinda et al. 2021). The index consists of the moisture contents of forest fuel and components related to fire behavior indices representing the rate of spread, fuel weight consumed, and fire intensity. The calculation is performed using meteorological data, including temperature, relative humidity, rainfall of the previous 24 hours, and wind speed, described in detail by Dowdy et al. (2009). The Canadian Forest Service classified the risk as null (0-2), small (2-5), average (5-9), high (9-17), and very high (>17).

\section{Fire events in the study area}

To quantify the number of fire events in the study site, we used a hotspot (fire detection) detection database (geographical position, date, and time) provided by the Brazilian National Institute for Space Research (INPE) from 2013 to 2016 (INPE 2017). The INPE database includes hotspots detected using nine satellites with optical sensors operating in the midthermal range of $4 \mu \mathrm{m}$. Each polar-orbiting satellite produces at least two images per day, and the geostationary satellites generate four images per hour. Each type of sensor has its algorithm to identify the pixels (spatial resolution element) with "radiometric temperature" above pre-defined thresholds, which are considered hotspots (INPE 2017).

Errors in the detection of fire events by hotspots are associated with the fire event size versus the pixel area, cloud and smoke cover, understory fires in mature forest stands, short-term burning that occurred between the hours of the available images, among others (Piromal et al. 2008; Schroeder et al. 2008).

We first analyzed the occurrence of fire events in the study area during the analysis period (2013-2016), defining the fire season (time of year when wildfires are most likely to ignite and spread) and comparing with the surrounding municipalities. We used the Visible Infrared Imaging Radiometer Suite (VIIRS) sensor onboard the Suomi National Polar-Orbiting Partnership (NPP-SUOMI) satellite as the reference for 
comparison between years and between Canaã dos Carajás and surrounding municipalities (Parauapebas, Eldorados dos Carajás, Marabá, Curionópolis, and Água Azul do Norte), since this will be the reference satellite used by INPE when the AQUA satellite ceases to operate.

The fire season was determined as the months that concentrated most of the study area's hotspots. Fire season months have lower precipitation, thus, the interference of cloud cover is lower, resulting in better fire detection by satellites. The separate analysis of the fire season is important because the firefighting structure is usually mobilized only in these months to reduce costs.

The entire database (hotspots detected using the nine satellites) was used to evaluate fire index performance during the fire season, as recommended by INPE when each fire detection is relevant. Although the total number of hotspots includes duplicate detections by more than one satellite, the combination of available satellites increased the chance of detecting a fire event (Pantoja and Brown 2007).

\section{Evaluation of fire index performance}

The performance of the indices (and the influence of the weather station used to generate them) was calculated by comparing the daily values of the indices with the occurrence of a fire event, which corresponds to the presence of one or more hotspots detected by remote sensing. This analysis was performed considering the fire events in all land uses of the municipality together and separately.

To evaluate the performance of the fire indices during the fire season, we standardized the performance of the computed indices, as they use different numbers of default fire hazard classes. For each index, we obtained the value of the index (threshold) that separated days with or without fire danger that maximized the Heidke Skill Score (SS) (Heidke 1926) and the Success Percentage (SP) (equations 8 to 11). The SS measures the fractional improvement of the forecast relative to forecasts generated based on chance. The SP indicates the percentage of days with a correct prediction of occurrence or no occurrence of fire events. A higher SS value corresponds to a greater adherence between the predicted and observed phenomenon, i.e., greater correspondence between predicting a fire event on a day and observing one or more hotspots on the same day. Days with a fire hazard index value less than the threshold were considered as days with no fire hazard.

$$
\begin{aligned}
& G=a+d \\
& N=a+b+c+d \\
& H=N \cdot\left(1-\frac{a+c}{N}\right) \cdot\left(1-\frac{a+b}{N}\right)+N \cdot\left(\frac{a+c}{N}\right) \cdot\left(\frac{a+b}{N}\right)
\end{aligned}
$$

$$
S S=\frac{G-H}{N-H}
$$

(equation 11)

$$
S P=\frac{G}{N}
$$

(equation 12)

where $\mathrm{G}$ is the number of hits in the forecast; $\mathrm{H}$ is the expected number of hits; $\mathrm{N}$ is the total number of observations; $\mathrm{a}$ is the number of days with a correct prediction of fire event(s); $\mathrm{d}$ is the number of days with a correct prediction of no occurrence of fire events; $b$ is the number of days with false alarms (prediction of fire events, but no fire events occurred); and $\mathrm{c}$ is the number of days with omission errors (fire events occurred, but they were not predicted).

Additionally, we assessed the performance of the fire indices in predicting the occurrence of more than a determined number of hotspots (1 to 12) in one day. A greater number of hotspots per day decreases the chance of error in the detection and indicated more fire outbreaks or larger fires, as each hotspot represents the center of a pixel flagged as containing one or more fires.

We also computed all the correlations between the number of daily hotspot detections and the raw values for each of the fire indices derived from each weather station during the fire season using general linearized models assuming a Poisson error distribution. The final models were validated by plotting the residual vs. fitted values and residual vs. predictor values and by analyzing the distribution of the residuals. Then, we ranked the twentyone models (seven different indices from each of three weather stations) of each LULC by decreasing the Akaike information criterion (AIC) using the model.sel function from the MuMIn package (Bartón 2020) within the R Environment. Models with the lowest AIC were considered the most parsimonious for explaining the fire frequency in Canaã dos Carajás. Additionally, we considered all models with a difference in AIC of less than two as equally parsimonious. For the best models, we computed the coefficient of determination.

\section{RESULTS}

\section{Hotspots in Canaã dos Carajás}

A total of 4,450 hotspots (including duplicates) were detected within the municipality by all satellites between 2013 and 2016: 232 in 2013, 738 in 2014, 1,576 in 2015 and 1,904 in 2016 (Figure 2). Using the reference satellite, Canaã dos Carajás presented a low value of hotspots per unit area from 2013 to 2015 in comparison with the surrounding municipalities (Supplementary Material, Figure S1). In 2016, 


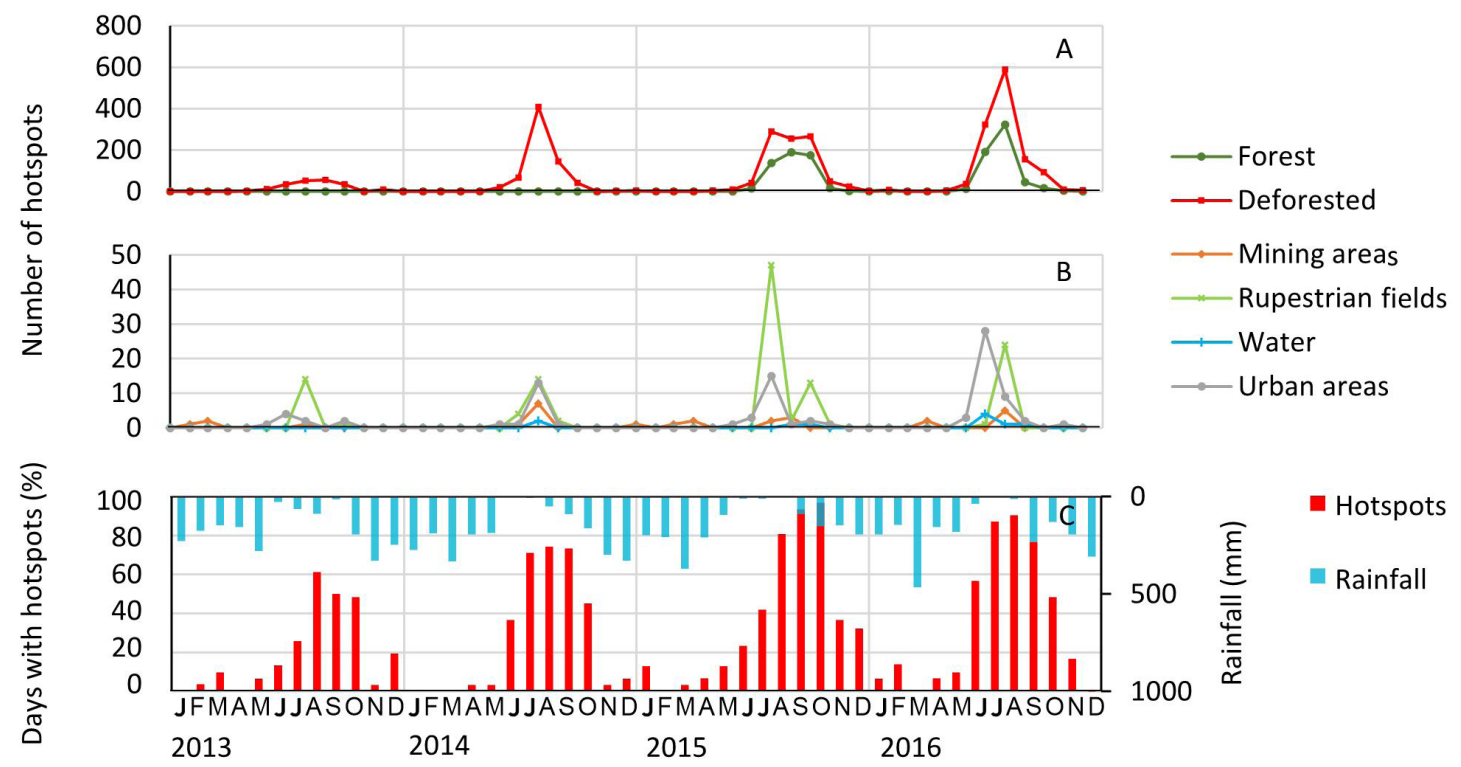

Figure 2. Monthly distribution of hotspots detected by nine satellites in the municipality of Canaã dos Carajás (Pará, Brazil) from January 2013 to December 2016. A - Number of hotspots in forest and deforested areas; B - Number of hotspots in mining, rupestrian, urban and water areas; C - Percentage of days with at least one hotspot and monthly rainfall. This figure is in color in the electronic version.

however, Canaã dos Carajás presented the highest value among the analyzed municipalities.

July to October accounted for $96 \%$ of all detected hotspots and only $14 \%$ of the total precipitation (Figure 2). Therefore, this period was considered as the fire season for the analysis of fire index performance.

Most of the hotspots (68.8\%) occurred in areas classified as deforested, followed by forest areas (25.5\%). Only a few hotspots were observed in other LULC classes: rupestrian field $(2.8 \%)$, urban areas $(2.0 \%)$, mining areas $(0.6 \%)$, and water bodies $(0.2 \%)$. The hotspots in pixels classified as water are probably due to the resolution of the classification map and the accuracy of the detection of the fire source. The percentage of hotspots that occurred in the two main land-cover types changed significantly over time. In 2013 and 2014, no hotspots were registered within forests, while in 2015 and 2016, 32.8\% of the hotspots occurred in forests. However, when considering the density hotspots in each land-cover type, deforested areas urban areas presented the highest values $\left(0.750\right.$ hotspots $\mathrm{km}^{2}$ year-1), and forests presented the lowest $\left(0.175\right.$ hotspots $\mathrm{km}^{-2}$ year $\left.{ }^{-1}\right)$, while deforested areas presented 0.550 hotspots $\mathrm{km}^{2}$ year $^{-1}$.

From 2013 to 2016, only 27 hotspots were detected inside the limits of the Carajás National Forest (Figure 1), which equals 0.0125 hotspots $\mathrm{km}^{2}$ year ${ }^{-1}$. In 2017, the Ferruginous Fields National Park was created within the municipality. A total of 805 hotspots (approximately 1.35 hotspots $\mathrm{km}^{2}$ ) were recorded inside the limits of the park between 2013 and 2016, mostly in the western region, which is subject to strong deforestation on the hill slopes.

\section{Fire index performance for all LULC classes}

Which weather station was used influenced the performance of the indices. For example, KBDI performed best among the seven indices considering all LULC classes with data from the Waste Pile station, but performed worst with data from the Process Plant station (Figure 3; Table 1). Considering all hotspots during the fire season for all LULC classes, the SS varied from 0.208 (FMA index with data from the Mine station) to 0.370 (KBDI with data from the Waste Pile station, although KBDI was $<0.25$ for the other two stations) (Table 2). The Waste Pile weather station is located at an intermediate altitude and situated between forest and deforested areas (Figure 1; Table 1). The second highest SS values were obtained for the FFDI, FWI and Angstrom index with data from the Process Plant station (SS > 0.362). This station is located at the lowest altitude, and is surrounded mainly by deforested areas, where most of the hotspots occurred.

The SP values varied less than the SS values. For the 21 combinations of the three weather stations with the seven indices, the SP varied from 0.681 (FWI and Waste Pile) to 0.736 (FWI and Process Plant) (Supplementary Material, Figure S2).

The fire season accounted for $82 \%$ of the days with more than one hotspot. The KBDI with data from the Waste Pile station provided the highest SS for 1 to 5 hotspots per day (Figure 4). The threshold for fire risk detection increased from 703.63 to 743.80 , above the default threshold (600) between the high and very high-risk classes and getting even closer to the maximum soil moisture deficit of 800 . For 6 to 12 hotspots per day, which indicate a higher fire risk, the best performance 

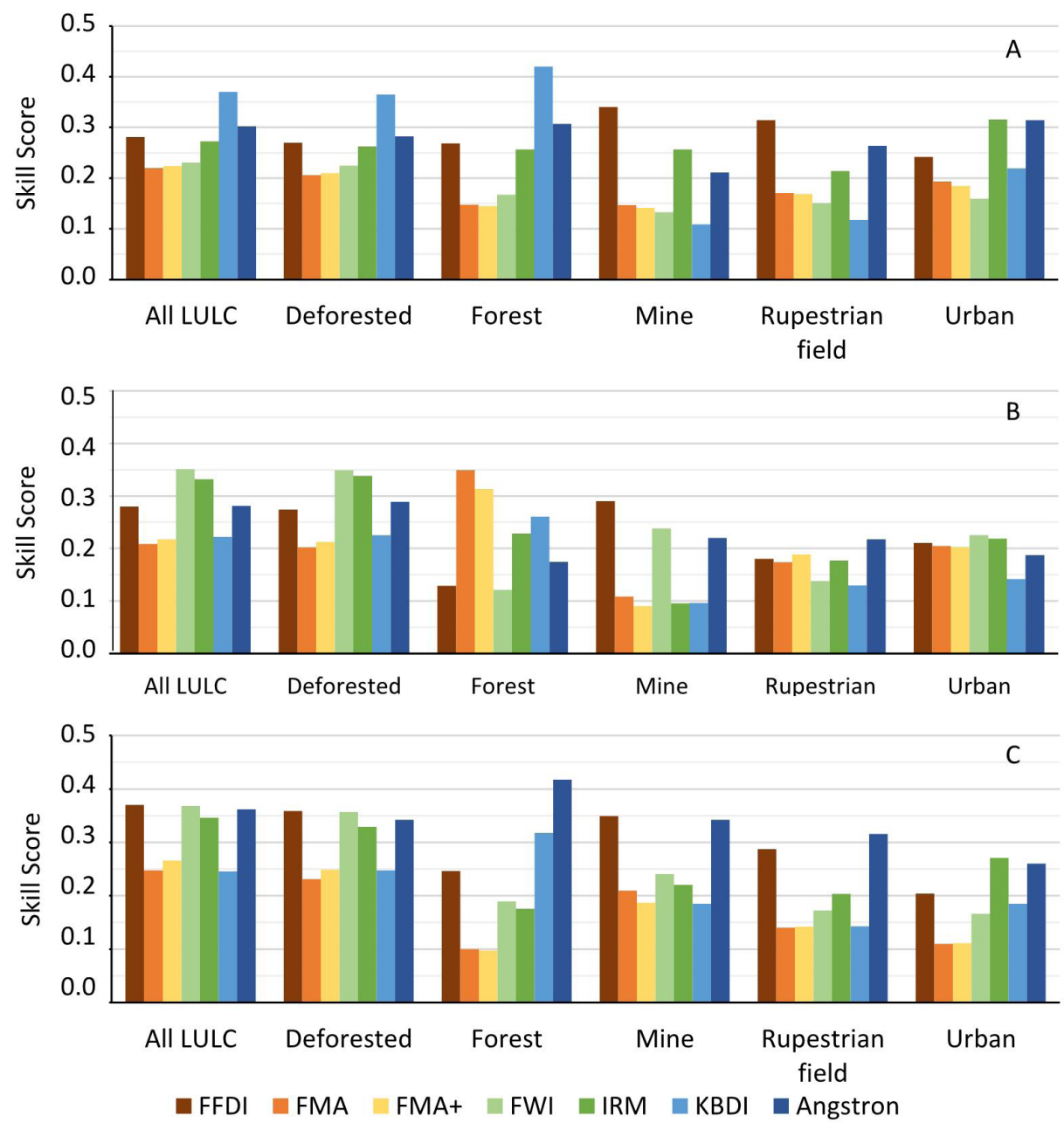

Figure 3. Skill scores of seven fire hazard indices for five land use and land cover (LULC) types in the municipality of Canaã dos Carajás (Pará, Brazil) computed with data from each of three meteorological weather stations. A - Waste Pile weather station; B - Mine weather station; C - Process Plant weather station. This figure is in color in the electronic version.

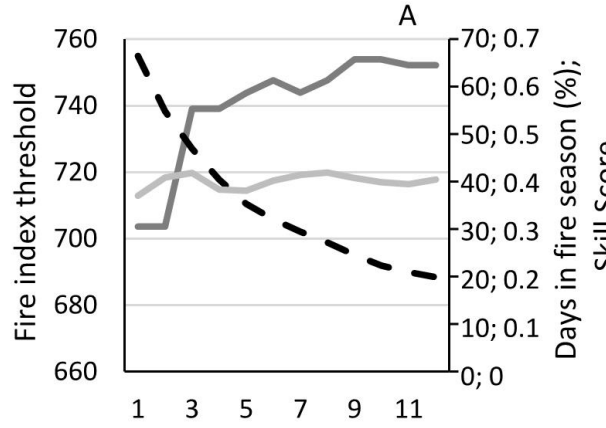

Minimum number of hot spots per day

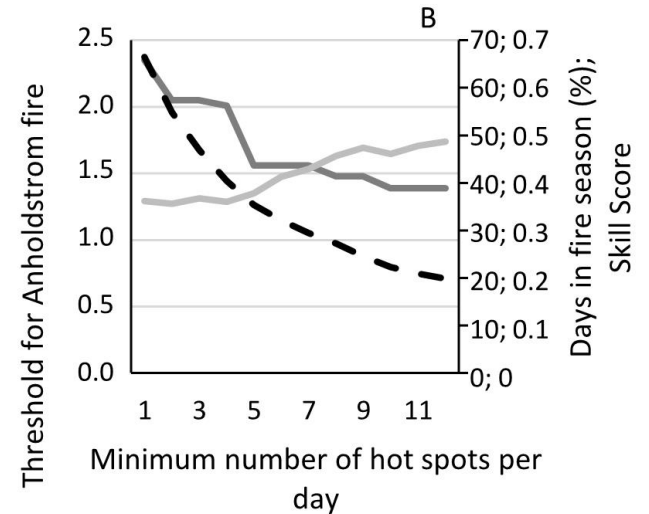

day

Fire index threshold $\quad-$ - Frequency (\%)

Skill Score

Figure 4. Threshold values for fire detection and skill scores of the KBDI (A) and Angstrom index (B) for the prediction of fire danger with at least one to 12 hotspots per day in Canaã dos Carajás (Pará, Brazil). The index values were obtained, respectively, with data from the Waste Pile and Process Plant weather stations. The percentage of days for each minimum number of hotspots per day during the fire seasons from 2013 to 2016 is also shown. 
Table 2. Two highest skill scores (SS) obtained for land use and land cover (LULC) types in Canaã dos Carajás municipality (Pará, Brazil) out of seven fire hazard indices tested with the data of each of three weather stations in 2013-2016. Order = first and second highest values. Weather stations: WP = Waste Pile; PP = Process Plant; $M=$ Mine. Index: Angstrom = Angstrom index; $I R M=$ Rodríguez and Moretti index $\mathrm{KBDI}=$ Keetch-Byram Drought Index; FFDI $=$ Forest Fire Danger Index .

\begin{tabular}{lccccc}
\hline LULC & Order & $\begin{array}{c}\text { Weather } \\
\text { station }\end{array}$ & Index & Limit & SS \\
\hline All & 1st & WP & KBDI & 703.63 & 0.37 \\
& 2nd & PP & FFDI & 34.45 & 0.37 \\
Forest & 1st & WP & KBDI & 739.03 & 0.42 \\
Deforested & 2nd & PP & Angstrom & 1.56 & 0.42 \\
area & 2nd & WP & KBDI & 703.63 & 0.36 \\
Mining area & 1st & PP & FFDI & 34.45 & 0.36 \\
Rupestrian & 2nd & PP & Angstrom & 138.89 & 0.35 \\
Field & 1st & PP & Angstrom & 0.75 & 0.34 \\
\multirow{2}{*}{ Urban area } & 2nd & WP & FFDI & 142.13 & 0.32 \\
\hline & 2nd & WP & IRM & 87.01 & 0.31 \\
\hline
\end{tabular}

was obtained using the Angstrom index and data from the Process Plant station, which showed an increase in SS and a decrease in the threshold as the minimum number of hotspots per day increased (Figure 4). For days with more than 12 hotspots, which corresponded to $20 \%$ of the days during the fire season, the threshold for fire risk was 1.39 (lower than the default value of 2.5), and the SS of the prediction was 0.49.

\section{Fire index performance per LULC type}

When the LULC types were analyzed separately, the performance between the indexes varied more than when all LULC types were analyzed together. The highest SS values were obtained using data from the Waste Pile station for forested, deforested, and urban areas, and from the Process Plant station for mining areas and rupestrian fields. However, a low number of hotspots in the latter LULC classes increased the uncertainty of the estimates.

The results for deforested areas (mainly pastures) were very similar to those for the joint LULC classes, as almost $70 \%$ of the hotspots occurred in deforested areas. For this LULC class, the highest SS was obtained with the KBDI index with data from the Waste Pile ( $S S=0.365)$, with similar results $(5 \%$ lower) for FFDI with data from the Process Plant station, and FWI with data from the Mine or Process Plant stations. For the forested areas, the best prediction was also obtained using the KBDI index and the Waste Pile station data (SS $=0.420$ ), with a similar performance of the Angstrom index with the Process Plant station data $(S S=0.417)$. For the other LULC types (mining areas, rupestrian fields, and urban areas), the SS values were lower than 0.349 .

The SP for all weather stations and fire indices were very similar among the LULC classes with a low number of hotspots (mining area, urban area, and rupestrian field) (Supplementary
Material, Figure S2). This is due to the high percentage of days without hotspots in these land uses, which resulted in a high ratio of nonfire hits by adopting a high index value as the threshold between days with or without fire hazard.

\section{Akaike information criterion}

Considering the results of the AIC, the Angstrom index performed best for the prediction of daily hotspot detection in the municipality for all LULC types except mining sites and urban areas, where the FFDI and IRM performed best (Supplementary Material, Table S3). In most cases, the Process Plant weather station data provided the best fit, although, for mining areas, the Waste Pile station provided the best fit. Only one model was selected in all cases. Determination coefficients varyied between 0.104 forurban areas and 0.437 for mining areas (Supplementary Material, Table S3).

\section{DISCUSSION}

\section{Hotspots in Canaã dos Carajás}

The number of hotspots per unit area was highest in urban areas, followed by pasture, probably due to the use of fire for pasture maintenance, which is common in the Amazon (Nepstad et al. 2006). The population increase associated with the installation of a large mining complex for iron exploration in the region, likely contributed to deforestation for urbanization purposes.

In 2015 and 2016, the number of days with hotspots in all LULC classes increased relative to 2013 and 2014. Notably, in 2015-2016, approximately one-third of the hotspots were detected in areas classified as forest, while no hotspots in these areas were detected in 2013-2014. The number of hotspots in forests during the latter years may have been overestimated, as a LULC classification of the area for 2017 (Nunes et al., 2019) showed that $6 \%$ of the forest area was deforested and $6 \%$ of the deforested areas was reforested relative to 2013. In 2015, a severe drought caused by El Niño occurred in eastern Pará state, which caused an abnormally long dry season and low levels of soil water storage in 2016 (Cavalcante et al. 2019). This phenomenon may explain the high number of days with hotspots at the beginning of the 2016 dry season despite normal rainfall. However, in the neighboring municipalities the number of hotspots decreased in 2016, which indicates that factors other than climate may have contributed to the high number of hotspots in 2016 in Canaã dos Carajás.

The number of hotspots per unit area in forests outside the Carajás National Forest was 14 times higher than that inside the reserve. Fire occurrence in protected areas in the Amazon is four to nine times lower than outside protected areas (Nepstad et al. 2006), indicating that the conservation status inhibits fires. Although remote sensors are not able to detect understory fires (Nepstad et al. 1999), extensive areas of primary forest create a microclimate that strongly reduces 
the probability of fire due to reduced temperature and higher relative humidity (Uhl and Kauffman 1990). Since the Ferruginous Fields National Park was only created in 2017, future monitoring should determine whether the protection of this area reduced the fire frequency, thereby contributing to better conservation of wildlife in the region.

We found that the period with the greatest fire occurrence in Canaã dos Carajás (July to October) does not begin immediately after the rainfall period. This agrees with Torres et al. (2017), who concluded that the period of higher fire occurrence begins two months after the end of the rainy period. During the dry season, because of the decrease in atmospheric humidity and soil moisture, potential evapotranspiration is supplied by soil water storage, progressively leading to drier fuels and more favorable atmospheric conditions for fire spread. Due to these changes, slash and burning activities also increase in these months.

\section{Fire hazard weather indices}

Depending on the patterns of climatic variables, some fire danger indices may generate better predictions than others (White et al. 2015). Although the three weather stations used in this study are located near each other (maximum distance of $17 \mathrm{~km}$ ), the differences in altitude (about $500 \mathrm{~m}$ overall range) and in the surrounding land use among stations cause differences in the meteorological variables, which in turn lead to a differential response of the tested fire indices regarding fire risk classification. Therefore, the choice of the best index to predict fire events is dependent on the weather data used, and once the index was chosen, a change in the weather data source used to calculate the fire index may compromise the accuracy of the fire occurrence prediction.

The Carajás Mineral Complex, which is partly located in Canaã dos Carajás, currently adopts the FMA+ index (Souza 2018), usually indicated as the best index in southern Brazil (Borges et al. 2011; Torres et al. 2010). However, our results indicated that other indices perform better in that area and could be used to improve the fire risk prediction.

The KBDI index with data from the Waste Pile weather station had the best SS to predict fire occurrence in forested and deforested areas. The KBDI is widely used in wildfire prediction (Heim 2002), and it estimates the soil moisture deficit. Since the index was calculated using the original values of the parameters, the model can be adjusted to the local climate or the parameters can be calibrated (e.g., the limit of daily precipitation to determine rainy days and the soil water available for evapotranspiration) to increase the fire prediction accuracy as discussed by Taufik et al. (2015). The best threshold values for this index for 1 to 6 hotspots per day were above the default value used to classify a day as having a "very high" fire potential. That is, using the default value would reduce the performance of the index for predicting fire risk in the study area.
Following the KBDI, the higher SS values were obtained using the FFDI and FWI for deforested areas, and the Angstrom and FMA indices for forested areas. Therefore, the incorporation of soil and fuel moisture parameters improved the fire prediction accuracy in areas with pasture, since the indexes that incorporate this variable performed better, but not for forest areas. The good performance of the simple, noncumulative Angstrom index is noteworthy, as it produced SS values only slightly below (1-2\%) the maximum SS values among all indices. It had the best performance in predicting days with more than six hotspots, although with a lower threshold value than the default value of the method, and was the best index based on the AIC. Other studies also observed good performance of the Angstrom index in the Amazon-Cerrado savanna transition zone (Casavecchia et al. 2019; França et al. 2014). As the Angstrom index is not cumulative, it may provide greater sensitivity to low rainfall values and better performance for days with no record of hotspots (Casavecchia et al. 2019).

\section{CONCLUSIONS}

Practically all hotspots in Canaã dos Carajás from 2013 to 2016 concentrated in July to October. Among all LULC classes in the municipality, forested areas presented the lowest density of hotspots, with a particularly low occurrence within protected areas, indicating that the preservation of large forest areas in conservation units inhibited fires. The choice of the best index to predict fire events was dependent on the weather station used. Therefore, if there is a change in the source of weather data used in the prediction of fire hazard, a new calibration of fire hazard index performance should be carried out. The performance of the seven tested fire hazard indices in predicting fire occurrence in the study area was not homogeneus among LULC classes. The KBDI index had the best overall average performance, as well as the best performance in forested and deforested areas, which account for the largest land cover area in Canaã dos Carajás. The user-friendly Angstrom index had the best performance in predicting days with more than six detected hotspots.

\section{ACKNOWLEDGMENTS}

Funding was provided by the Instituto Tecnológico Vale and Vale S.A. We would like to thank Mario Luis Oliveira, Cesar de Sá Carvalho Neto, and José Camilo Araújo for their help in obtaining weather data. We thank the editors and the anonymous reviewers whose comments helped to improve and clarify the manuscript.

\section{REFERENCES}

Alvares, C.A.; Stape, J.L.; Sentelhas, P.C.; Gonçalves, J.L. de M.; Sparovek, G. 2013. Köppen's climate classification map for Brazil. Meteorologische Zeitschrift, 22: 711-728. 
Alvares, C.A.; Cegatta, I.R.; Vieira, L.A.A.; Pavani, R.F.; Mattos, E.M.; Sentelhas, P.C.; Stape, J.L.; Soares, R.V. 2014. Forest fire danger: application of Monte Alegre Formula and assessment of the historic for Piracicaba, SP. Scientia Forestalis, 42: 521-532.

Angstrom, A. 1942. Riskerna for skogsbrand och deras beroende av vader och klimat (The risks for forest fires and their relation to weather and climate). Svenska Skogsvirdsforeningens Tidskrift, 40: 323-343.

Bartón, K. 2020. MuMIn: Multi-Model Inference. R Package Version 1.43.17. (https://cran.r-project.org/web/packages/MuMIn/ MuMIn.pdf).

Borges, T.S.; Fiedler, N.C.; Santos, A.R. dos; Loureiro, E.B.; Mafia, R.G. 2011. Desempenho de alguns índices de risco de incêndios em plantios de eucalipto no norte do Espírito Santo. Floresta e Ambiente, 18: 153-159.

Casavecchia, B.H.; Souza, A.P. de; Stangerlin, D.M.; Uliana, E.M.; Melo, R.R. 2019. Fire danger indices in the transition area of Cerrado-Amazonia. Revista de Ciências Agrárias, 42: 842-854.

Cavalcante, R.B.L.; Pontes, P.R.M.; Tedeschi, R.G.; Costa, C.P.W.; Ferreira, D.B.S.; Souza-Filho, P.W.M.; Souza, E.B. 2019. Terrestrial water storage and Pacific SST affect the monthly water balance of Itacaiúnas River Basin (Eastern Amazonia). International Journal of Climatology, 40: 3021-3035.

Chitale, V.; Behera, M.D. 2019. How will forest fires impact the distribution of endemic plants in the Himalayan biodiversity hotspot? Biodiversity and Conservation, 28: 2259-2273.

Chuvieco, E.; Aguado, I.; Yebra, M.; Nieto, H.; Salas, J.; Martín, M.P.; et al. 2010. Development of a framework for fire risk assessment using remote sensing and geographic information system technologies. Ecological Modelling, 221: 46-58.

Dowdy, A.J.; Mills, G.A.; Finkele, K.; Groot, W. 2009. Australian fire weather as represented by the McArthur Forest Fire Danger Index and the Canadian Forest Fire Weather Index. CAWCR Technical Report No. 10, Bureau of Meteorology/CSIRO, 91p.

Finkele, K.; Mills, G.A.; Beard, G.; Jones, D.A. 2006. National daily gridded soil moisture deficit and drought factors for use in prediction of forest fire danger index in Australia. Australian Meteorological Magazine, 55: 183-197.

França, G.B.; Oliveira, A.N. de; Paiva, C.M.; Peres, L. de F.; Silva, M.B. da; Oliveira, L.M.T. de. 2014. A fire-risk-breakdown system for electrical power lines in the north of Brazil. Journal of Applied Meteorology and Climatology, 53: 813-823.

Gaigher, R.; Pryke, J.S.; Samways, M.J. 2019. Divergent fire management leads to multiple beneficial outcomes for butterfly conservation in a production mosaic. Journal of Applied Ecology, 56: $1322-1332$.

Gerwing, J.J. 2002. Degradation of forests through logging and fire in the eastern Brazilian Amazon. Forest Ecology and Management, 157: 131-141.

Heidke, P. 1926. Berechnung des Erfolges und der Gute der Windstarkevorhersagen im Sturmwarnungsdienst (Measures of success and goodness of wind force forecasts by the gale-warning service). Geografiska Annaler, 8: 301-349.

Heim, R.R. 2002. A review of twentieth-century drought indices used in the United States. Bulletin of the American Meteorological Society, 83: 1149-1166.
Holsten, A.; Dominic, A.R.; Costa, L.; Kropp, J.P. 2013. Evaluation of the performance of meteorological forest fire indices for German federal states. Forest Ecology and Management, 287: 123-131.

INPE. 2017a. Instituto Nacional de Pesquisas Espaciais. Programa de queimadas - Banco de dados de queimadas. (https://queimadas. dgi.inpe.br/queimadas/portal). Accessed on 19 Oct 2021.

Johnston, L.M.; Wang, X.; Erni, S.; Taylor, S.W.; McFayden, C.B.; Oliver, J.A. et al. 2020. Wildland fire risk research in Canada. Environmental Reviews, 28: 164-186.

Keetch, J.J.; Byram, G.M. 1968. A drought index for forest fire control. US Department of Agriculture-Forest Service, Asheville, 32 p.

Liu, Y.; Goodrick, S.L.; Stanturf, J.A. 2013. Future U.S. wildfire potential trends projected using a dynamically downscaled climate change scenario. Forest Ecology and Management, 294: 120-135.

Marle, M..J.E.; Field, R.D.; Werf, G.R.; Wagt, I.A.E.; Roughton, R.A.; Rizzo, L.V.; Artaxo, P.; Tsigaridis, K. 2017. Fire and deforestation dynamics in Amazonia (1973-2014). Global Biogeochemical Cycles, 31: 24-38.

Masinda, M.M.; Li, F.; Qi, L.; Sun, L.; Hu, T. 2021. Forest fire risk estimation in a typical temperate forest in Northeastern China using the Canadian forest fire weather index: case study in autumn 2019 and 2020. Natural Hazards, 2021: 1-15. doi. org/10.1007/s11069-021-05054-4

Mbanze, A.A.; Batista, A.C.; Tetto, A.F.; Romero, A.M.; Mudekwe, J. 2017. Desempenho dos índices de Nesterov e fórmula de Monte Alegre no distrito de Lichinga, norte de Moçambique. Ciência Florestal, 27: 687-696.

McArthur, A.G. 1967. Fire Behaviour in Eucalypt Forests. Department of National Development Forestry and Timber Bureau, Canberra, Leaflet 107, 36p.

Miranda, E.E.; Moraes, A.V.C.; Oshiro, O.T. 2006. Queimadas na Amazônia Brasileira em 2005. Comunicado Técnico 18, EMBRAPA, Campinas, 19p.

Nepstad, D.C.; Moreira A.G.; Alencar A.A. 1999. Flames in the Rain Forest: Origins, Impacts and Alternatives to Amazonian Fire. The Pilot Program to Conserve the Brazilian Rainforest/World Bank, Brasilia, 161p.

Nepstad, D.; Schwartzman, S.; Bamberger, B.; Santilli, M.; Ray, D.; Schlesinger, P.; et al. 2006. Inhibition of Amazon deforestation and fire by parks and indigenous lands. Conservation Biology, 20: 65-73.

Noble, I.R.; Gill, A.M.; Bary, A.V. 1980. McArthur's fire-danger meters expressed as equations. Australian Journal of Ecology, 5: 201-203.

Nogueira, J.M.P.; Rambal, S.; Barbosa, J.P.R.A.D.; Mouillot, F. 2017. Spatial pattern of the seasonal drought/burned area relationship across Brazilian biomes: sensitivity to drought metrics and global remote-sensing fire products. Climate, 5: 1-21. doi:10.3390/ cli5020042

Nunes, J.R.S.; Soares; R.V.; Batista, A.C. 2006. FMA+ - um novo índice de perigo de incêndios florestais para o estado do Paraná, Brasil. Floresta, 36: 75-91.

Nunes, S.; Cavalcante, R.B.L.; Nascimento, W.R.; Souza-Filho, P.W.M.; Santos, D. 2019. Potential for forest restoration and deficit compensation in Itacaiúnas Watershed, southeastern Brazilian Amazon. Forests, 10: 439. doi.org/10.3390/f10050439 
Pantoja, N.V.; Brown, I.F. 2007. Acurácia dos sensores AVHRR, GOES e MODIS na detecção de incêndios florestais e queimadas a partir de observaçóes aéreas no estado do Acre, Brasil. Anais XIII Simpósio Brasileiro de Sensoriamento Remoto, INPE, p.4501-4508.

Piromal, R.A.S.; Rivera-Lombardi, R.J.; Shimabukuro, Y.E.; Formaggio, A.R.; Krug, T. 2008. Utilização de dados MODIS para a detecção de queimadas na Amazônia. Acta Amazonica, 38: 77-84.

Pletsch, M.; Penha, T.V.; Junior, C.H.S.; Körting, T.; Aragão, L.E.C. de; Anderson, L. 2018. Integração do algoritmo FMASK ao modelo linear de mistura espectral como subsídio à detecção de áreas queimadas na Amazônia brasileira. Revista Brasileira de Cartografia, 70: 696-724.

Ray, D.; Nepstad, D.; Moutinho, P. 2005. Micrometeorological and canopy controls of fire susceptibility in a forested amazon landscape. Ecological Applications, 15: 1664-1678.

Rodríguez, N.; Moretti, A. 1988. Índice de peligro de propagación de incêndios forestales. VI Congreso Forestal Argentino, Santiago del Estero, Tomo III: 704-709.

Rodríguez, M.P.R.; Soares, R.V.; Batista, A.C.; Tetto, A.F.; Sierra, C.A.M.; Rodríguez, Y.C. 2012. Ajuste e desempenho dos índices de perigo de incêndios Nesterov, FMA e FMA+ na empresa florestal Macurije, Cuba. Floresta, 42: 651-660.

Schroeder, W.; Alencar, A.; Arima, E.; Setzer, A. 2009. The spatial distribution and interannual variability of fire in Amazonia. In: Keller, M.; Bustamante, M.; Gash, J.; Dias, P.S. (Ed.). Amazonia and Global Change. American Geophysical Union, Washington, D.C., p. 43-60.

Schroeder, W.; Ruminski, M.; Csiszar, I.; Giglio, L.; Prins, E.; Schmidt, C.; Morisette, J. 2008. Validation analyses of an operational fire monitoring product: The Hazard Mapping System. International Journal of Remote Sensing, 29: 6059-6066.

Silvestrini, R.A.; Soares-Filho, B.S. ; Nepstad, D.; Coe, M.; Rodrigues; H.; Assunção, R. 2011. Simulating fire regimes in the Amazon in response to climate change and deforestation. Ecological Applications, 21: 1573-1590.

Soares, R.V. 1972. Determinação de um indice de perigo de incêndio para a regiäo centro paranaense, Brasil. Master's thesis, Instituto Interamericano de Ciências Agrícolas da OEA, Costa Rica, 72p.

Souza, B.M. de. 2018. Avaliação de indices de perigo de incêndios florestais em Canaã dos Carajás - PA. Master's dissertation, Instituto Tecnológico Vale, Brazil, 117p. (https://www.itv. org/wp-content/uploads/2019/07/Souza-Bruno-Moreira-de.Avalia\%C3\%A7\%C3\%A3o-de-\%C3\%ADndices-de-perigode-inc\%C3\%AAndios-florestais-em-Cana\%C3\%A3-dosCaraj\%C3\%A1s-PA.-PROD.-TEC.-ITV-DS-N005_2018.pdf)
Souza-Filho, P.W.M.; Giannini, T.C.; Jaffé, R.; Giulietti, A.M.; Santos, D.C.; Nascimento, W.R.; Guimarães, J.T.F.; Costa, M.F.; Imperatriz-Fonseca, V.L.; Siqueira, J.O. 2019. Mapping and quantification of ferruginous outcrop savannas in the Brazilian Amazon: A challenge for biodiversity conservation. PLoS ONE, 14: e0211095.

Souza-Filho, P.W.M.; Souza, E.B. de; Júnior, R.O.S.; Nascimento, W.R.; Mendonça, B.R.V. de; Guimarães, J.T.F.; Dall'Agnol, R; Siqueira, J.O. 2016. Four decades of land-cover, land-use and hydroclimatology changes in the Itacaiúnas River watershed, southeastern Amazon. Journal of Environmental Management, 167: 175-84.

Taufik, M.; Setiawan, B.I.; van Lanen, H.A.J. 2015. Modification of a fire drought index for tropical wetland ecosystems by including water table depth. Agricultural and Forest Meteorology, 203: 1-10. doi.org/10.1016/j.agrformet.2014.12.006

Taylor, S.W.; Alexander, M.E. 2006. Science, technology; human factors in fire danger rating: the Canadian experience. International Journal of Wildland Fire, 15: 121-135.

Torres, F.T.P.; Lima, G.S.; Martins, S.V.; Valverde, S.R. 2017. Analysis of efficiency of fire danger indices in forest fire prediction. Revista Arvore, 41: e410209.

Torres, F.T.P.; Ribeiro, G.A.; Martins, S.V.; Lima, G.S. 2010. Determinação do período mais propício às ocorrências de incêndios em vegetação na área urbana de Juiz de Fora, MG. Revista Árvore, 34: 297-303.

Uhl, C.; Kauffman, J.B. 1990. Deforestation, fire susceptibility; potential tree responses to fire in the eastern Amazon. Ecology, 71: 437-449.

Van Wagner, C.E. 1987. Development and structure of the Canadian forest fire weather index system. Technical Report nr. 35, Canadian Forestry Service, Ottawa, 35p.

Varela, V.; Sfetsos, A.; Vlachogiannis, D.; Gounaris, N. 2018. Fire weather index (FWI) classification for fire danger assessment applied in Greece. Tethys, 15: 31-40.

White, L.A.S.; White, B.L.A.; Ribeiro, G.T. 2015. Evaluation of forest fire danger indexes for eucalypt plantations in Bahia, Brazil. International Journal of Forestry Research, 2015: 613736.

Ziccardi, L.G.; Thiersch, C.R.; Yanai, A.M.; Fearnside, P.M.; Ferreira-Filho, P.J. 2020. Forest fire risk indices and zoning of hazardous areas in Sorocaba, São Paulo state, Brazil. Journal of Forestry. 31: 581-590.

RECEIVED: $10 / 04 / 2021$

ACCEPTED: 02/10/2021

ASSOCIATE EDITOR: Matheus H. Nunes 
SUPPLEMENTARY MATERIAL (only available in the electronic version)

Cavalcante et al. Assessment of fire hazard weather indices in the eastern Amazon: a case study for different land uses
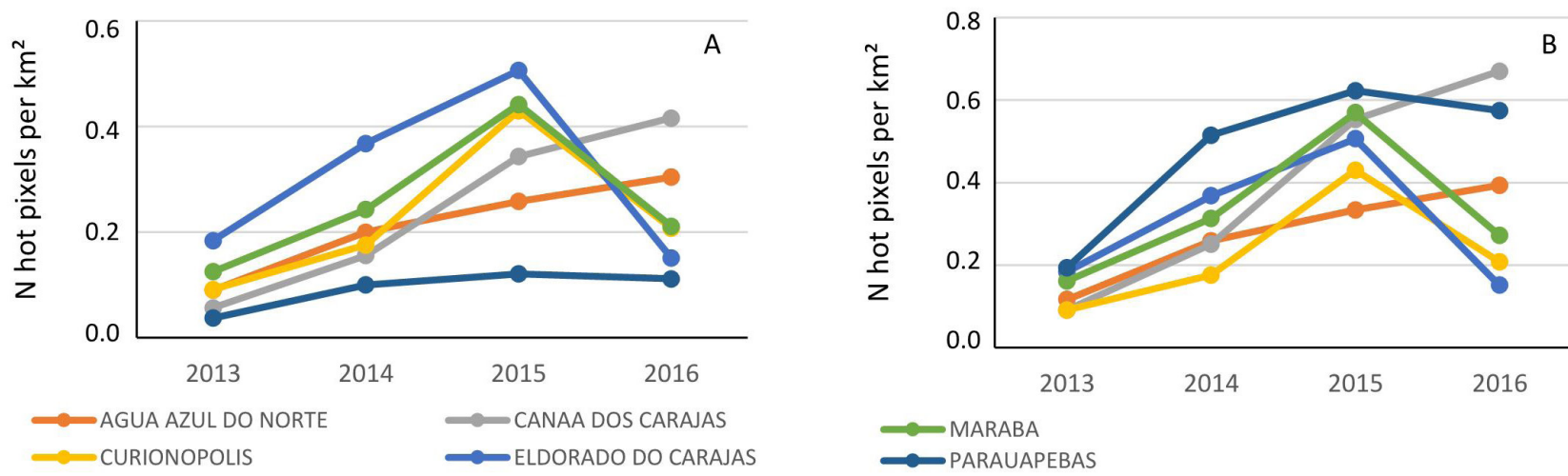

Figure S1. Annual number of hotspots per $\mathrm{km}^{2}$ detected using the reference satellite (Suomi National Polar-Orbiting Partnership) in six municipalities in eastern Pará state (Brazil) from 2013 to 2016. A - Total area of the municipality; B - Nonprotected area of the municipality.
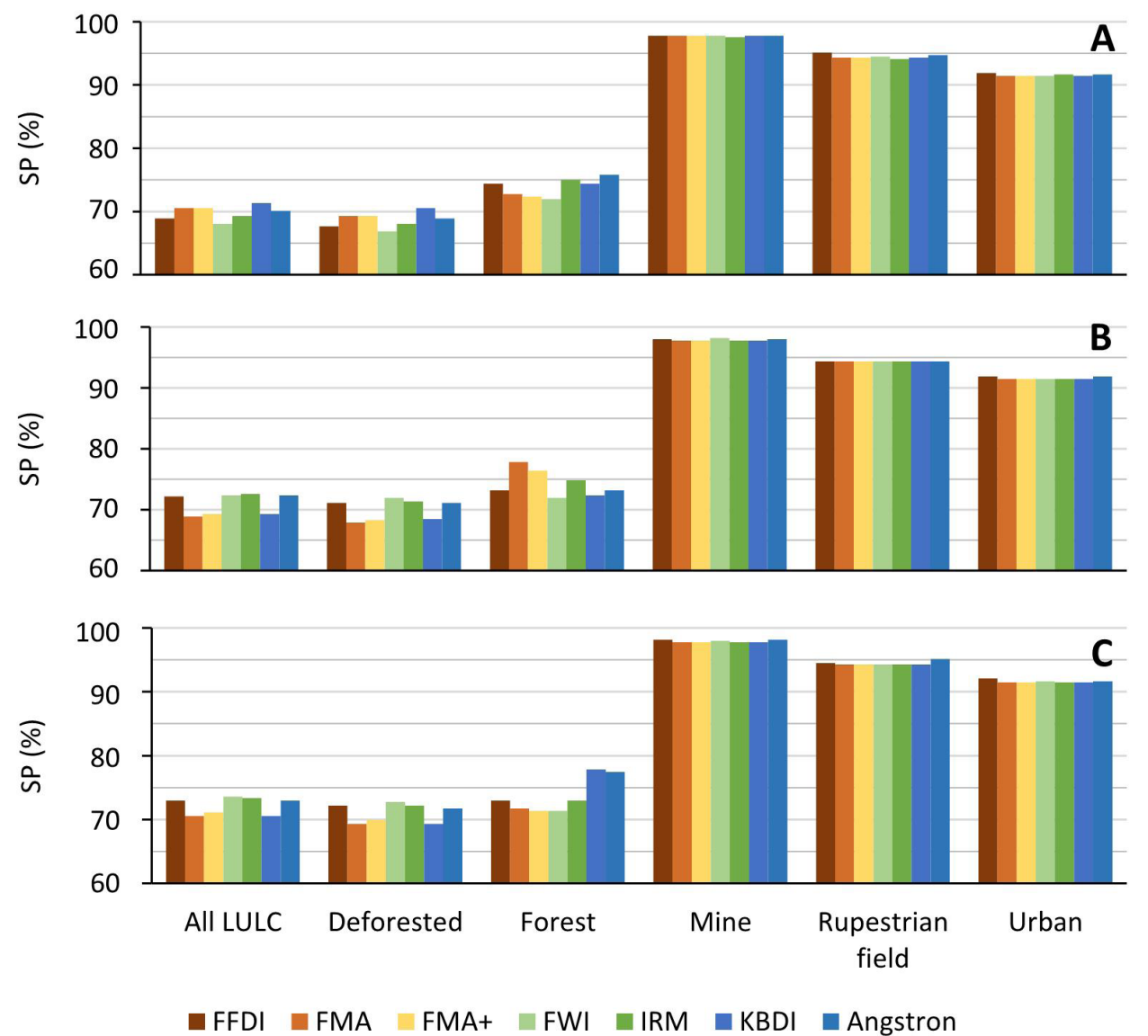

Figure S2. Success percentage (SP) of seven fire hazard indices computed from meteorological data collected at three weather stations for five land use and land cover (LULC) classes in the municipality of Canaã dos Carajás (Pará, Brazil). Weather stations: A - Waste Pile; B - Mine; C - Proccess Plant. 
Table S1. Daily accumulator for the fire hazard Rodriguez and Moretti Index (Rodríguez and Moretti 1988).

\begin{tabular}{|c|c|c|c|c|c|c|c|}
\hline \multicolumn{2}{|c|}{ Acumulator 1} & \multicolumn{2}{|c|}{ Acumulator 2} & \multicolumn{2}{|c|}{ Acumulator 3} & \multicolumn{2}{|c|}{ Acumulator 4} \\
\hline $\begin{array}{l}\text { Temperature } \\
\text { at } 15 \mathrm{~h}\left({ }^{\circ} \mathrm{C}\right)\end{array}$ & Index & $\begin{array}{l}\text { Wind speed } \\
(\mathrm{km} \mathrm{h}-1)\end{array}$ & Index & $\begin{array}{c}\text { Relative } \\
\text { humidity (\%) }\end{array}$ & Index & $\begin{array}{c}\text { Days without } \\
\text { rain }\end{array}$ & Index \\
\hline$<10$ & 2.5 & $<3$ & 1.5 & $>80$ & 2.5 & 1 & 3.5 \\
\hline $10-1.9$ & 5.0 & $3-5.9$ & 3.0 & $79-75$ & 5.0 & $2-4$ & 7.0 \\
\hline $12-13.9$ & 7.5 & $6-8.9$ & 4.5 & $74-70$ & 7.5 & $5-7$ & 10.5 \\
\hline $14-15.9$ & 10.5 & $9-11.9$ & 6.0 & $69-65$ & 10.5 & $8-10$ & 14.0 \\
\hline $16-17.9$ & 12.5 & $12-14.9$ & 7.5 & $64-60$ & 12.5 & $11-13$ & 14.5 \\
\hline $18-19.9$ & 15.5 & $15-17.9$ & 9.0 & $59-55$ & 15.0 & $14-16$ & 21.0 \\
\hline $20-21.9$ & 17.5 & $18-20.9$ & 10.5 & $54-50$ & 17.5 & $17-19$ & 24.5 \\
\hline $22-23.9$ & 20.0 & $21-23.9$ & 12.5 & $49-45$ & 20.0 & $20-22$ & 28.0 \\
\hline $24-25.9$ & 22.5 & $24-26.9$ & 13.5 & $44-40$ & 22.5 & $23-25$ & 31.5 \\
\hline$>26$ & 25.0 & $>27$ & 15.0 & $<39$ & 25.0 & $>26$ & 35.0 \\
\hline
\end{tabular}

Table S2. Modification of the Formula Monte Alegre (FMA) index as-function of daily precipitation (Soares 1972). $\mathrm{H}$ = relative humidity.

\begin{tabular}{|c|c|}
\hline $\begin{array}{l}\text { Daily } \\
\text { precipitation } \\
(\mathrm{mm})\end{array}$ & Modification \\
\hline$\leq 2.4$ & None \\
\hline $2.5-4.9$ & $\begin{array}{l}\text { Reduce } 30 \% \text { on the FMA index calculated the day before and } \\
\text { add }(100 / H) \text { for the day }\end{array}$ \\
\hline $5.0-9.9$ & $\begin{array}{l}\text { Reduce } 60 \% \text { on the FMA index calculated the day before and } \\
\qquad \text { add }(100 / H) \text { for the day }\end{array}$ \\
\hline $10.0-12.9$ & $\begin{array}{l}\text { Reduce } 80 \% \text { on the FMA index calculated the day before and } \\
\text { add }(100 / H) \text { for the day }\end{array}$ \\
\hline$>12.9$ & Stop calculation $(F M A=0)$ and restart sum the following day \\
\hline
\end{tabular}

Table S3. Best general linearized models describing the correlation between daily number of hot spots during the fire season (July-October) for each land use and land cover (LULC) type in Canaã dos Carajás (Pará, Brazil) from 2013 to 2016. The models ran on data for seven fire hazard indices from three weather stations. Angstrom $=$ Angstrom index; FFDI $=$ Forest Fire Danger Index; $\mid \mathrm{RM}=$ Rodríguez and Moretti index. Weather station: $\mathrm{PP}=$ Process Plant; WP $=$ Waste Pile. $\mathrm{AlC}=$ Akaike information criterion.

\begin{tabular}{lcccc}
\hline LULC & Weather station & Index & AIC & $\mathbf{R}^{\mathbf{2}}$ \\
\hline All & PP & Angstron & 6760.7 & 0.379 \\
Forest & PP & Angstron & 2994.2 & 0.312 \\
Deforested area & PP & Angstron & 5078.6 & 0.305 \\
Mining area & PP & FFDI & 120.3 & 0.437 \\
Rupestrian fields & PP & Angstron & 580.1 & 0.233 \\
Urban area & WP & IRM & 420.4 & 0.104 \\
\hline
\end{tabular}

